\title{
Teaching Implementation of MOOC and Flipped Classroom
}

\author{
Fan Zhang \\ Central South University of Forestry \& Technology, Hunan, China \\ Shuxiong Feng \\ University of Delaware, DE, USA
}

\begin{abstract}
The paper introduced the construction of flipped classroom teaching model based on MOOC. It discussed the overall lesson preparation and class guidance, then analyzed how evaluate teaching effect. It shed light on changing teaching concepts, course arrangement of College English, cooperative teaching, and learning successful experience of MOOCs. Then it indicates application strategies of MOOCs in college English teaching. Future implications of implementations of the teaching model are also discussed.
\end{abstract}

Keywords: construction; overall lesson preparation; application strategies.

\section{INTRODUCTION}

The ministry of education has issued the education informatization development plan (20112020). Information technology has penetrated into every aspect of economic development and social life, thus people's mode of production, life style and learning style is undergoing profound changes. Personalized learning and life-long learning have become important issues of education development in the information age.

However, there are still many difficulties and challenges in accelerating educational information. The understanding of the important role of educational information needs to be deepened and improved. The effective mechanism of co-construction and sharing of digital education resources has not been formed, and the quality education resources are especially scarce. Educational management information system needs to be integrated and integrated. Under this background, the teaching model combining MOOC and flipped classroom has gained increasing attention from educators all over the world.

\section{CONSTRUCTION OF FLIPPED CLASSROOM TEACHING MODEL BASED ON MOOC}

The flipped classroom extends the concept of "personalized learning" of MOOCs, while MOOCs provide better video resources for the flipped classroom. The author believes that flipped classroom teaching mode based on MOOCs should include the following processes (as shown in table 1) : 
Table 1 flipped classroom teaching process based on MOOCs

\begin{tabular}{|l|l|}
\hline Before class & $\begin{array}{l}\text { Teachers analyze the teaching content according to the } \\
\text { characteristics of learners and select appropriate teaching } \\
\text { methods. } \\
\text { Teachers record teaching video and upload it to MOOC platform } \\
\text { in time. } \\
\text { Students watch teaching video, ask students to record the doubts } \\
\text { and difficulties in the video learning process, and fill in the } \\
\text { independent learning task sheet. }\end{array}$ \\
\hline In class & $\begin{array}{l}\text { Teachers listen to students' feedback on the teaching effect of } \\
\text { video. } \\
\text { The teacher answers the questions and difficulties encountered } \\
\text { by the students and organizes the relevant class discussion or } \\
\text { group cooperation activities. }\end{array}$ \\
\hline After class & $\begin{array}{l}\text { According to the feedback of students, further revision of } \\
\text { teaching video is made. }\end{array}$ \\
\hline
\end{tabular}

\section{OVERALL LESSON PREPARATION AND PRE-CLASS GUIDANCE}

Make a study list. Learning task sheet, which is called "learning guidance sheet" or "learning ability sheet", is an instructional design sheet to guide teachers and students' teaching and learning activities before and during the flipped classroom teaching, which clearly shows the learning objectives and tasks, learning contents, learning methods and homework that students need to complete. The study task list can be sent to students in paper form or in the electronic form to the teaching platform. Learning task sheet can guide the whole teaching activities of teachers and students; more importantly, it can also guide students' pre-class study. Especially when flipped classroom teaching mode is adopted at the beginning, learning task list is a "crutch" to help teachers and students better complete teaching tasks, which is of great value to guarantee and improve the teaching quality of flipped classroom.

The study task list generally includes study goal, content, method, difficult homework questions, what to do in class and so on. Students complete pre-class self-study tasks under the guidance of the study task list to smoothly enter the classroom teaching and learning activities. College English teaching mainly includes basic language knowledge of English vocabulary, sentence patterns, and grammar, involving listening, speaking, reading, writing, translating ability, intercultural communication and learning strategies. According to the teaching content of college English course and the actual English level of students, teachers make flipped classroom study task list, self-test questions before class and after class. The setting of learning task list can introduce students into the new course teaching and use the guided learning plan to attract students' interest in learning. In the traditional teaching mode, teachers tend to integrate each course content into the whole course teaching step by step and promote students' consolidation and internalization of content through a large number of homework exercises after class. The flipped classroom based on MOOC integrates the teaching contents into video of MOOC so that students can independently learn video contents. Combined with the learning task list, students can also clearly know what to learn before class, how to learn, what degree to learn. Teachers can also more conveniently detect students' learning situation, and better target flipped class. See table 2 for the template of the autonomous learning task list. 
Table 2 template of an independent learning task list

\begin{tabular}{|l|}
\hline Study guide \\
(The subject of the study material.) \\
2. Achieve goals \\
(different from teaching objectives.) \\
\hline 3. Suggestions on learning methods \\
(video combines with self-study, thinking, and finally exercises independently.) \\
\hline 4. Classroom learning form preview \\
(Make students understand the relationship between autonomous learning and \\
classroom learning in advance. A brief description of the organization of \\
classroom teaching. The flowchart can also be used instead. The purpose is to \\
make students understand the relationship between autonomous learning and \\
classroom internalization.) \\
\hline Study tasks \\
\hline 1. Create structure maps \\
(Grasp the overall framework of the learning content.) \\
\hline 2. Guide students to complete the following learning tasks by watching \\
video resources produced: \\
(test questions, exercises, and helpful information such as necessary hints.) \\
\hline 3. Learn \\
(review the independent learning process, refine the learning method, discovery, \\
perception, and other gains.) \\
\hline Confusion and Suggestions \\
\hline $\begin{array}{l}\text { (what doubts or new questions did you have during the Mooc? Alternatively, } \\
\text { give suggestions to the teacher.) }\end{array}$ \\
\hline
\end{tabular}

Compile teaching micro-video. Compared with paper learning materials, video integrates sound, image, animation, color, and other factors, which is more conducive to stimulating students' various learning senses and meeting the needs of different learning styles. If the video compiled by the teacher is of high quality and students like it, it will be of great help to students' knowledge mastery. However, in practice, the explanation is not clear, vivid, and even noise interference will not help students understand the new knowledge of the due effect.

Many teachers worry about students' persistence, that is, in the beginning, students will be interested in this new form, but after a while, they are not so interested in video learning. In this regard, on the one hand, a variety of security mechanisms should be established to ensure the continuity of students' video learning. For example, teachers can monitor through the learning platform to check students' completion of homework or summary writing and reflection. Students cannot continue to watch to drag and drop. At the same time, to obtain the understanding and support of parents, at the beginning of the class, students are organized to talk about feelings centering on video learning.

On the other hand, the quality of the video also affects the sustainability of the video.The establishment of high-quality teaching micro-video is of great value to the successful and continuous promotion of flipped classroom teaching.

For making teaching micro-video, the MOOC center of East China Normal University puts forward the viewpoint of "low threshold, easy to make and high quality"(Tian, 2014). "Low threshold" means that it is easy for teachers to learn how to make micro-video. For example, teachers can learn how to make micro-video by recording PPT documents with Camtasia 
Studio's screen recording software. Generally speaking, teachers can learn within 10 minutes, and it is not difficult to learn how to make micro-video with other kinds of tools. Many universities have gradually provided teachers with educational technology training, among which recording software to record micro-lessons is one of the teaching contents. "Easy to make" refers to the simple and convenient operation of the recording process. If video production is very complicated, some schools start to set up a team to record 10 minutes of micro video. "High quality" refers to the production of video quality is high; students love to learn can learn well. of course, it is not easy to produce high-quality teaching micro-video, which requires teachers to carefully design, carefully try to figure out, clarify the teaching objectives and so on. Generally speaking, there are two main factors that determine the quality of micro-video: first, the presentation form of video conforms to the nature of subject teaching. For subjects such as science, chemistry, and biology, it is necessary to consider better how to use video to present demonstrative experiments and explain concepts and principles at the same time. Video of "khan academy" style is compiled in the form of writing board, which is more in line with the requirements of the nature of these disciplines.

College English class needs to introduce more audio video content related to the content of the text, in order to train students' listening, cultivate students' interest, and promote the internalization of knowledge. Second, video is presented in a way that meets the learning needs and characteristics of students. For example, video is more easily accepted by students by inserting more cases, events, pictures, and animations that are closely related to students' life.

At the beginning of micro-lesson and flipped class, video on the Internet is not much, and teachers need to compile by themselves, which will increase teachers' workload to some extent. Over time, online video quality gradually increased. Teacher could make and select the online video for their own use, resulting in that the burden of the teacher to prepare micro videos will gradually reduce.

Prepare lessons for the second time. The end of pre-class teaching is the starting point of classroom teaching. This fully explains the importance of teachers to check and analyze students' learning situation and prepare lessons for the second time before classroom teaching begins. "Second lesson preparation" refers to the process of lesson preparation after the end of pre-class teaching (after students learn video and other learning materials, complete assignments, and conduct online communication and discussion) and before the beginning of in-class teaching. The teacher fully understands the students' learning situation and redesigns and adjusts the classroom teaching.

Obviously, the premise of the second lesson plan and preparation is that the teacher fully understands the students' pre-class learning situation, that is, to grasp the learning situation. With the support of information technology and online learning platform, teachers' understanding of students' pre-class learning is based on data analysis rather than personal subjective experience judgment. Although experience judgment is significant for experienced teachers, with the support and help of the learning platform, teachers will have a more specific and objective understanding of each student's learning situation. Through the learning platform, teachers and parents can clearly know the students' online time, including start time, end time, and the pause in the middle of the time. Besides, the repetition of the same situation, basic condition of the job completion, the time required for completing advanced operation will be known.

Based on the information recorded on the learning platform, teachers should make clear what students have learned through pre-class self-study, and what kind of help and guidance should 
be given to these students in class. How should teachers explain and coach these students so that they can overcome cognitive obstacles and meet the basic requirements of course standards?

\section{FLIPPED CLASSROOM TEACHING}

The main task of the flipped classroom teaching is to develop students' high-level cognitive ability and cultivate their overall quality, such as helping students consolidate internal knowledge, exercise and improve ability, cultivate students' emotional attitudes and values, more hands-on practice, exploration, and creation. With the convenience brought by information technology, students with similar learning levels are assigned to a group according to their self-study before class. Some groups need to focus on explaining concepts, some groups need to focus on experimental operations, and some groups can expand and deepen more. However, at present, many schools are still unable to make such timely grouping or class walking. Under the current class teaching system, flipped classroom teaching mainly has the following tasks:

Self-study consolidation. In order to improve students' overall English application ability and independent learning ability, teachers should carry out listening, speaking, reading, writing, translating and other activities when designing classroom activities, so that students can apply what they have learned to achieve the internalization and absorption of English knowledge. The following are some specific activities that are more suitable for the internalization of English knowledge: (1) show and explain. In combination with what they have learned, students introduce some characters, things, and phenomena through objects or multimedia in class in the form of individuals or groups, and express their emotions. (2) Roleplay. For the text with a story, students can be required to act according to the content of the text, allowing students to increase their imagination and play properly. (3) Film and television dubbing. English films can be watched before class. In class, activities are mainly combined to cultivate students' enthusiasm in learning English, such as English dialogue imitation, social and cultural analysis, line translation, movie-watching experience sharing, etc. (4) five-minute speech. Collect some positive, let the students prepare speeches in advance, express their viewpoints adequately.

Solve problems. In the process of cooperative exploration of group tasks, students are divided into groups of 5 to 8 people. Each group take the teacher's role in the classroom, to teach other groups about his team's teaching tasks and organize the discussion. The group members work together to design methods and operational processes of target tasks, and complete new problems in the process of discussion. Teachers guide students to carry out learning activities and give appropriate hints to ensure the smooth development of group activities. Teachers explain students' problems and systematically summarize the knowledge structure and key points and difficulties of this class.

Summarize. Before the end of the class, students can make an oral summary or complete a test sheet assigned by the teacher. The main content of the summary is to sort out the main knowledge points, the relationship between knowledge points, learning methods, and ideas, etc..

Prepare for the Next Topic. It needs to be emphasized that if the teacher teaches flipped class, the homework questions will be completed in class because the students learn microlesson before class. Therefore, at the end of class, there is no need to assign the homework of this class, and all homework questions should be completed and solved in class. If homework is assigned at the end of the class, it is a preview of the next study project, rather than an exercise of what has been learned in the class. The exercises of this lesson are completed in class, which 
is particularly important and should be paid attention to by teachers. Otherwise, students should not only carry out micro-lesson learning before class, but also carry out in-class exercises and finish homework after class, which objectively lengthens students' learning time and aggravates students' schoolwork burden.

\section{TEACHING EFFECT ANALYSIS}

The teaching effect evaluation mainly involves two forms, namely, the examination paper and the questionnaire investigation. The examination paper mainly evaluates the comprehensive application ability of students' English knowledge, including listening, speaking, reading, writing and translating. The questionnaire survey mainly includes the evaluation of MOOCs teaching modes, such as teaching attitude, teaching method, and teaching effect.

Zhang (2016) found that the excellence rate of students in MOOCs is significantly higher than that of students in MOOCs, showing a significant progress trend. The vast majority of students show positive interest in the model. The research results show that the flipped classroom teaching model of college English based on MOOCs can achieve good teaching results and gain public recognition of students, which should be widely promoted and applied.

\section{APPLICATION STRATEGIES OF MOOCS IN COLLEGE ENGLISH TEACHING Change the Teaching Concept}

The application of MOOCs in English teaching has a substantial impact on students' academic performance, which requires teachers to realize the critical role of MOOCs in English teaching reform in the network era. Under the background of MOOCs, teachers have changed from the dominant and controller of classroom teaching to the guide and promoter of students' learning. Students use the online learning platform to learn knowledge. There are abundant videos on the internet, and students can learn knowledge at home, in school, or even anywhere at any time. However, the learning process of students still needs the guidance of teachers. Some universities have introduced the superstar learning platform, through which teachers and students can exchange questions and discuss with each other. Teaching evaluation standards have to be completed requiring the joint efforts of teachers and schools. The integration and application of resources on the MOOC platform is an essential challenge for teachers.

\section{Pay Attention to Course Arrangement of College English}

The biggest difference between MOOCs and traditional teaching mode is that MOOCs simplifies teachers' classroom teaching. The 45-minute content of classroom teaching is compressed into video resources of MOOCs, so the course flow arrangement of MOOCs is crucial. Teachers should arrange various teaching resources reasonably to optimize the design of the MOOC teaching process. College English teaching goal is to improve students' ability to use English, thus the teacher should be helpful for students' future career development, such as training students to work in the real scenario for the use of English.

\section{CONCLUSION}

Cooperative learning under MOOCs not only refers to the student group cooperation in class but also includes the cooperative discussion among teachers. MOOC is a new teaching mode in the network era. It mainly relies on advanced network information technology, and it needs the cooperation and discussion of college English teachers in the establishment and use of MOOC platform and the production of MOOC video resources.

Teachers in China should cooperate with the foreign MOOC platforms of teaching resources to understand and learn different courses, strengthen the exchanges and cooperation with other colleges and universities, establish and improve the suitable class curriculum system for China's colleges and universities. 
ACKNOWLEDGEMENT

This paper is supported by A Teaching Reform Project in Hunan Province: "An Empirical Study on the Flipped-Classroom Teaching Mode of College English Based on Micro-lessons" and China Scholarship Council.

\section{References}

Ash, K. (2012). Educators view "flipped" model with a more critical eye. Education Week, 32(2), 6-7.

Bergmann, J., \& Sams, A. (2012). Flipping the classroom (pp. 42-43). San Bruno: Tech \& Learning.

Berrett, D. (2012). How "flipping" the classroom can improve the traditional lecture. The Chronicle of Higher Education. Retrieved August 12, 2014 from http://chronicle.com/article/How-Flipping-the-Classroom/130857/

Chen Y, Tian A. Introduction to MOOCs and flipped classroom [M]. Shanghai: East China Normal University Press, 2014.

Fox,A.,Patterson,D.A.\&Ilson,R.etal.(2014). Software Engineering Curriculum Technology Transfer: Lessons Learned from MOOCs and SPOCs[R]. UC Berkeley Technical Report.

Fulton, K. (2012). Upside down and inside out: Flip your classroom to improve student learning. Learning and Leading With Technology, 39(8), 12-17.

Herreid, C. F., \& Schiller, N. A. (2013). Case studies and the flipped classroom. Journal of College Science Teaching, 42(5), 62-66.

Kathleen F. Upside Down and Inside Out: Flip Your Classroom to Improve Student Learning [J]. Learning and Leading with Technology. 2012 (6)

Mangan, K. (2013). Inside the flipped classroom. Chronicle of Higher Education, 60(5), 18-21.

Perna, L. W. Ruby A. Life cycle of a million MOOC users. Invited presentation at the MOOC Research Initiative Conference[R]. Arlington, Texas, 2013.

Sams, A., \& Bergmann, J. (2013). Flip your students' learning. Educational Leadership, 7, 16-20.

Tian A. Theory and practice of MOOCs and flipped classroom teaching in basic education [M]. Shanghai: East China Normal University Press, 2014.

Zhang, F. (2016a). A study of the autonomous learning model of college English reading under the MOOC environment. Aussie-Sino Studies, 10, 47-48.

Zhang, F. (2016b). Outline signal teaching method and college English reading teaching under the environment of MOOC. AMAHS International Conference, 12, 457-460.

Zhang, F. (2016c). Research on teaching performance evaluation of college English based on MOOC. Journal of Residuals Science \& Technology, 13(8), 200.1-200.4.

Zhang, F. (2017a). Quality-improving strategies of college English teaching based on microlesson and flipped classroom. English Language Teaching, 10(5), 243-249.

Zhang, F. (2017b). Research on the college English teaching mode of "Internet+Flipping the classroom". International Journal of Intelligent Information and Management Science, 6(2), 57-58. 